\title{
岩手県における高等学校教育サービスの地域的変化と 高等学校への進学行動
}

\begin{abstract}
石 郷 岡 信 行*
要 旨本研究では, 岩手県を事例に高校教育におけるサービス供給の地域差と高校進学行動の関係 について分析した。その結果，以下のことが明らかになった。

教育サービスの供給には，量と質の両面において地域差が存在する。量的な面では，1965 年 以降の 30 年間に全地域でサービス供給量の相対值が増大したが, 県の西部地域で值が高く, そ の他の地域で低いという地域間の格差構造があり, その構造は 1965 年と 1995 年の両年次にお いて確認できる。また, 専門学科の設置, 学校規模, 教員の配置を指標として質的側面からサー ビス供給を検討したが，量的地域差とほぼ同様の格差構造が確認された。

また，各地域におけるサービス供給量の相対值と高校進学率の関係をみると，1965 年の段階 では強い正の相関がみられた。しかし，1995 年になると進学率の地域差がなくなり，両者の関 連は薄れている。これは, 全県的な所得水準の向上や教育に対する人々の意識の変化などが背 景にあると考元ら机る。さらに，岩泉ブロックを対象としたミクロスケールの分析の結果，縁 辺地域での高校の新設や交通条件の改善も進学率の向上に影響していることが明らかとなっ た。

キーワード 教育サービス, 地域差, 進学行動, 高等学校, 岩手県
\end{abstract}

\section{I.はじめに}

ピンチ (1990, pp. 8-13) は, 各種の財やサービス を「純粋公共財」,「純粋地方財」,「非純粋地方財」, 「純粋私的財」の 4 類型に区分し，そのうち「非純粋 地方財」については，地方政府の管轄域や供給地点 からの距離などに応じて, 供給される財やサービス の量や質に地域差が生じやすいとしている。そして, 教育サービスを含む公共サービスの多くをこのカテ ゴリーに分類している。教育の機会均等の理念に照 らすなら，居住地域の如何に関わらず，個人の能力 に応じた平等な教育サービスの受容があらゆる国民 に保障されるべきである。しかし，現実の教育サー ビスの供給に際しては，上の指摘のように地域間の 格差が生じている可能性が高い。
ところで，マイヤーほか (1982，pp. 27-30) は，社 会地理学の研究対象となりうる人間の行動様式とし て，「居住する」，「労働する」などとともに「教育を 受ける」をあげ，教育を地理学的視点から研究する ことの意義を説いている。しかし，「公共財とサービ スの配分に対する空間の重要性にもかかわらず，こ れまで言及してきた研究者たちの中に地理学者はほ とんど含まれていない」とピンチ $(1990$, p. 16) が指 摘しているように, 教育サービスを含む公共サービ 又供給の空間構造は, 従来の地理学研究において主 要なテーマとされることが少なかった。その背景に ついて, マイヤーほか (1982, pp.164-165) は, 「教 育という機能の発揮が景観要素として形相の上に直 接目に見える形で現われるのは，点状に（中心地に 集中して）つくられた『場所化した施設』の形であ

* 岩手県立大迫高等学校 T 028-3203 岩手県稗貫郡大迫町大迫 9-19-1 
るにすぎず，居住機能や労働機能が景観に対して面 状に刻印を与えるのとは全く反対だからである」と 説明している。

わが国においても，教育サービス供給の地域差を 分析した地理学的研究は例が少ない。例えば，原田 （1985）は，「教育サービス」とほぼ同様の意味で「教 育環境」という概念を用い，初等教育機関から高等 教育機関までの在学者比率や学校の立地密度などを 指標とし，教育環境に格差が存在することを都道府 県別に示している。酒川 $(1994,1998)$ は，都市地域 における年少人口の減少が小学校教育に及ぼす影響 を解明しようとする中で，学校規模をサービス水準 の質的指標とみなした分析を行い，小学校の小規模 化の様相には都市間の差異とともに都市内の地区間 の差異が存在するとの知見を得ている。

これらとは別に，学校施設の立地パターンや教育 水準の地域差の解明を試みた論考に扔いて，付随的 に教育サービスの地域的差異の問題に言及した例が ある。例えば，石郷岡（1991）は，過疎地域におけ る小学校の統廃合のパターンを分析する中で学校規 模の問題に触れ，人口密度の低い縁辺地域では，教 育サービスの水準が質的に劣る小規模校であって も, 統廃合の対象となりにくいことを報告している。 川田 $(1992,1993)$ は，教育水準の地域格差の実態や そうした地域格差が再生産されてゆく過程を分析し ているが，その中で大学の立地状況に言及し，大学 レベルの教育サービスの供給に量的な地域差が存在 することを示している。また，川田 $(1997,1998)$ は， 専門学校の立地が尃門分野ごとに異なるパターンを 示すことや大学進学率などの面で都市部の高校と郡 部の高校で格差があることなどを明らかにしてい る。

以上が教育サービス供給の地域差に関わる主な既 存研究であるが,研究例自体が少ないことに加えて, 次のような課題が指摘できる。まず，既存研究はい ずれも限られた年次の実態把握という静態的分析に
とどまっており，教育サービス供給の空間構造が社 会状況の推移とともにどのように変化したかという 動態的分析がなされていない。また, 居住地域によっ て通学先が自動的に決められる義務教育学校と異な り，高校以上の段階ではサービス供給の地域差が進 学先の選択にも影響すると予想される。しかし，こ の問題についても川田（1998）が断片的に論及した だけで，本格的に検討された例がない。

これらの事実は，それぞれの時代における教育 サービスの供給体制が教育の機会均等を実現する上 で妥当なものであったか，あるいは時代とともに状 況は改善されたかという点について，客観的な検証 がなされてこなかったことを示している。そして,こ のことは，教育行政当局の決定によって行われる学 校施設の新設や統廃合が，これまで教育サービス供 給の空間構造についての詳細な分析を欠いたまま進 められてきたことをも意味する。

そこで本研究では, 岩手県の高等学校を取り上げ, サービス供給の地域差の実態を動態的に明らかに し，市わせてサービスの供給状況と高校への進学行 動の関連性を把握することを目的とする。

教育におけるサービス供給の地域差を明らかにす ることは，教育行政上の各種施策を進める上で重要 であると同時に，一般の住民に対しても各自の居住 地域において享受しうる教育サービスの水準を他地 域との比較の上でチェックする方途を提供すること につながると考えられる。

詳細は以後の分析によって明らかにするが，広大 な面積を有する岩手県の場合，かつては，都市地域 と農山漁村地域の間で，高校レベルの教育サービス の供給状況に厳然たる格差が存在したと予想され る。特に農山漁村地域では，高校への通学自体が不 可能な地域も少なからず存在したはずである かし，やがて農山漁村地域にも高校が設置されるよ うになったことからサービス供給の地域差が縮小 し，同時に交通条件の改善や所得水準の向上，人久 
の教育に対する意識の変化なども進み, 現在のよう に，居住地域に関係なく，ほとんどの中学校卒業者 が高校に進学するようになったと考えられる。ただ， 今日においても，人々が利用しうる高校教育サービ スの内容や高校への進学行動のパターンには, 地域 差が残存すると思われる。

以下ではまず次章において対象地域の概観と分 析方法の整理を行ったあと，第 III 章で高校教育に おけるサービス供給の地域差を量的な面と質的な面 に分けて分析する。そして，それらの結果を受けて， 第 IV 章では，教育サービスの供給状況と高校への 進学行動の関係を岩泉ブロックを事例として分析す る。

\section{II. 研究対象地域と研究方法}

\section{1. 研究対象地域}

本研究では，岩手県を研究対象地域とする（第 1 図）。同県を大まかに区分するとまず北上川流域の 平野を中心とする西部地域は，藩政時代から開発が 進み，首都圏に直結する交通手段にも惠まれ，県内 で経済活動の最も活発な地域とみなされている。一 方，北上山地から太平洋沿岸の南東地域や北東地域 は，山地が多いことから交通の便が悪く，各種の社 会資本や産業基盤の整備も遅れ，経済的に停滞傾向 にあるとされている。また，各地域の内部において は，都市的地域と農山漁村的地域が明瞭に分れて分 布している。このように，岩手県は経済的な発達の 程度や都市化の進展度合についての地域的対照が把 握しやすく，地域の特性に対応させながら教育サー ビスの特徵を観察する上で，好適な条件を有する。

ところで，高度経済成長期を通じて高校進学率が 大幅に上昇したのは全国的な趨勢であるが，そうし た傾向は，岩手県において特に顕著にあらわれてい る。すなわち，1965 年に 53.4\%であった岩手県の高 校進学率は, 1967 年に 60\%, 1971 年に 70\%, 1974 年 に $80 \%$ に達し，その後も1980 年に $90 \%$ を超え,

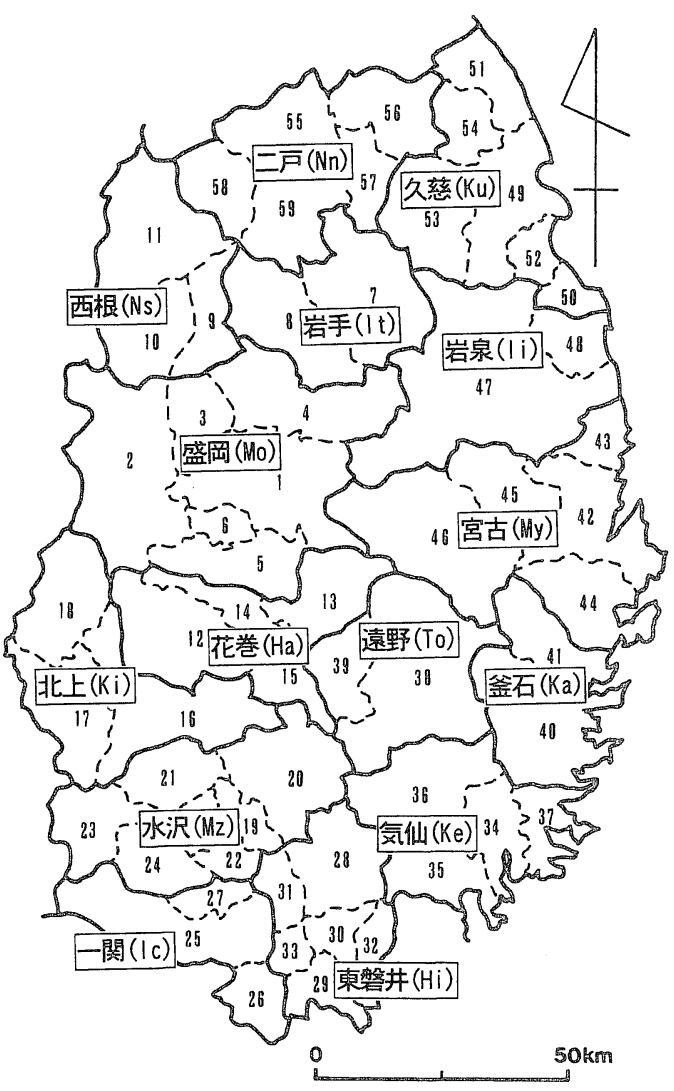

第 1 図研究対象地域

実線：ブロック界，破線：市町村界 (1995 年当 時)，盛岡ブロック (1: 盛岡市，2：雫石町，3： 滰沢村，4：玉山村，5：紫波町，6：矢巾町） 岩手ブロック (7: 葛巻町，8：岩手町）西根ブ ロック (9: 西根町, 10: 松尾村, 11 安代町) 花巻ブロック (12：花巻市，13：大迫町，14： 石鳥谷町，15：東和町） 北上ブロック（16：北 上市，17：湯田町，18：沢内村） 水沢ブロッ ク（19：水沢市，20：江刺市，21：金ヶ崎町, 22 : 前沢町, 23：胆沢町，24：衣川村）一関 ブロック（25：一関市，26：花泉町，27：平泉 町）東磐井ブロック (28：大東町，29：藤沢 町，30：千龎町，31: 東山町，32：室根村, 33：川崎村）気仙ブロック（34：大船渡市， 35：陸前高田市，36：住田町，37：三陸町) 遠野ブロック (38：遠野市，39：宮守村）釜石 ブロック (40: 釜石市， 41 : 大桘町) 宮古ブ ロック (42：宮古市，43：田老町，44：山田町, 45: 新里村， 46 : 川井村）岩泉ブロック（47: 岩泉町，48：田野畑村）久慈ブロック (49：久 慈市，50：普代村，51：種市町，52：野田村, 53 : 山形村，54：大野村）二戸ブロック（55： 二戸市，56：軽米町，57：九戸村，58：浄法寺 町，59：一戸町）

図中の枠内の地名およびアルファベット記号は ブロック名を示す。 
1995 年には $97.4 \%$ に達している は，主に高校の新設や募集定員の増加などといった 教育サービスの供給体制自体の変化によってもたら されたと推測され，この点においても岩手県は本研 究の目的にかなったフィールドといえる。

なお，上記の高校進学率の上昇は，所得水準や交 通条件の改善，さらには教育に対する人々の意識の 高まりも要因になっていると考えられる。実際,「岩 手県統計年鑑」(岩手県統計調查課発行) によると, 岩手県の 1 人あたり 分配所得は, 1965 年に全国平均 值の $77.6 \%$ であったものが，1995 年には 85.1\%と なり，格差を縮めている。また，1960 年代以降，当 時の国鉄東北本線の複線化と電化の完成 (1968 年), 太平洋沿岸地域を縦貫する国道 45 号線の全通 (1972 年）や三陸縦貫鉄道の開業（1984 年）など，高校へ の通学条件の改善に寄与するような交通機関の整備 も進んでいる。さらに，岩手県教育委員会(1964)で は，教育に対する保護者の意識の程度を測る指標と して, 小中学校の在籍者に占める長期欠席者 ( 1 年間 に50日以上学校を欠席した児童·生徒）の比率を挙 げているが，それによると，1961 年当時，岩手県で は, 小学校で $0.89 \%$, 中学校で $2.17 \%$ の長期欠席者 があり，その理由として，「家事手伝い」や「㙰困家 庭の無関心」などといった出身家庭の経済状態や保 護者の意識に原因が求められる事例が約半数を占め ている ${ }^{3)}$ 。一方, 1995 年の文部省問題行動調査による と,岩手県で 1 年間に 30 日以上学校を欠席した不登 校児童・生徒の比率は小学校 0.14\%, 中学校 1.08\% であるが，いじめや児童・生徒個々の精神的な問題 が原因となっている事例が大半で，貧困や保護者の 無理解が理由とされるケースはほとんどみられな w。

\section{2. 研究方法}

1）分析単位地区の設定

義務教育学校では, 大部分の通学流動が市町村の 領域内で完結する。これに対して, 高校では市町村
域を越えた通学流動が多く, 高校の通学区域も複数 の市町村をまとめて設定される傾向にある。岩手県 でも，公立高校の普通科については，1995 年の時点 で 19 の通学区域が設定されているが, 単独の市町村 で 1 つの通学区域を構成する事例は存在しない。し かも, 個々の公立普通科高校は, 1977 年までは 20\%, それ以降は $15 \%$ を上限として通学区域外からの入 学者の受け入れが可能とされ，また公立高校の普通 科以外の専門学科および私立高校については通学区 域制度自体が存在しない。よって, 本研究の場合, 個々の市町村を分析の最小単位とするのは不適当と 判断した。そこで, 公立普通科高校の通学区域の構 成，青野・尾留川編 (1975, pp. 390-391) に示された 教育事務所や県の地方振興局をはじめとする各種行 政機関の管轄区域，岩手県内の通勤流動に関する後 藤 (1980) おょび木村 (1994) の整理 ${ }^{4}$ をもとに，結 びつきの強い隣接市町村をグループ化し，「ブロッ ク」と称する地域単位を設定した。以後の分析は, 主 にこのブロックを最小単位として行う。

な扔，前節に扔いて岩手県内を西部地域，南東地 域, 北東地域に区分したが, 以下では盛岡, 花巻, 北 上, 水沢, 一関の 5 ブロックを西部地域, 東磐井, 気 仙，遠野，釜石の 4 ブロックを南東地域，岩手，西 根，宮古，岩泉，久慈，二戸の 6 ブロックを北東地 域と称する（第1図）。

2）教育サービスに扔ける質と量の規定

酒川 $(1990,1997)$ は，英国における初等・中等教 育および成人教育のサービス供給を検討する中で, サービスの量的地域差を教育施設の立地状況から， 質的地域差を学校規模や提供される教育プログラム の内容から定義している。これに倣い，本研究にお いても，教育サービスは量的な側面と質的な側面に 分けられるとの前提に立ち, 以後の分析を進める。

このうち, サービス供給の「量」を示す指標とし て，酒川 $(1990,1997)$ が教育施設の立地数を用いた のに対し, 本研究では, 各ブロックにおける中学卒 
業者数に対する高校入学定員の比率を指標とする。 以後，この指標を「収容指数」と呼ぶ。収容指数は， 值が大きいほどサービス供給量が相対的に多いこと を意味する。

また，サービス供給の「質」を示す指標としては， 各ブロックにおける高校の学科構成, 学校規模, 教 員の構成を用いる。このうち, 学科構成と学校規模 については，酒川 $(1990,1997)$ においても類似した 指標が用いられているが，教員の構成に着目するの は本研究独自の視点である。

まず「学科構成」については，受験生に対してよ り多くの選択肢が用意されている状態，すなわち各 ブロックに扔いて1つでも多くの学科系統が設置さ れている状態を質的に良好な教育サービスとみな す。また, 1 つの学校内で専門学科が普通科などと併 設されるタイプより，工業高校や農業高校のような 専門学科の独立校に設置されるタイプの方をより良 好な教育サービスと解釈する。これは，專門学科を 指導した経験を有する高校教員からの聞き取りによ ると，専門学科ではその学科の専門性に配慮した教 員の配置や実習等に関わる特殊な施設・設備が必要 となることから，専門学科の独立校の方が学校運営 上の混乱が少なく，充実した教育活動を行いやすい とされていることによる。

次に,「学校規模」であるが, 本研究では, 各学校 の生徒数をもって学校規模を示す指標とする。とこ ろで，大規模校と小規模校はそれぞれに長所と短所 があると思われるが，小学校から高校までの各段階 における教育内容や教育活動の性質を考えると, 小 規模校に入学したことによって児童・生徒が被る不 利益の程度は，上級学校浮ど大きくなると考えられ る。例えば，中学校と高校では教員免許状が教科ご とに分れており，個々の授業担当者の専門性が充実 した教科指導を展開する上での重要な要素となる が, 小規模校は教員定数が少なく, 1 人の教員が専門 外の教科や科目まで担当させられるような事例が生
じやすい。また，大規模校と小規模校双方での勤務 経験を有する高校教員からの聞き取りによると，小 規模校では，団体競技的な課外活動が制約されたり， PTA 会費等の収入が少ないことから学校運営に関 わる財政基盤が脆弱で，教育活動や学校内の環境整 備などに支障が生じるなどといった事態が起こりや すいという。さらに，上級学校への進学や課外活動 の成績などでも，大規模校において優れた実績が残 される傾向がある゙5。こうしたことから，本研究で は，大規模校の増加を教育サービスの質的水準の向 上とみなす。

最後に，「教員の構成」であるが，この指標は，各 学校における教員の世代構成と同一校における在職 年数という 2 通りのとらえ方があると考光る。この うちの前者については，学校現場の教員には校務の 処理や生徒との対応などの点で個々の教職経験や年 齢に応じた役割が期待されることから，各学校にお いて若手からべテランまでバランスのとれた教員構 成がなされている状態を質的に良好な教育サービス とみなす。一方，後者の場合，教員の同一校におけ る在職年数は長短气れぞれに利点があると考えられ るが，本研究では，同一校に長期にわたつて在職す る教員ほど生徒に対する継続的な指導が行いやす く，同時に校務の運営や保護者・地域住民への対応 などの点で一貫性を保持しやすくなることを重視 し，在職年数の長い教員が多い状況を質的に良好な 教育サービスとみなすこととする ${ }^{6)}$ 。

3）「動態」把握の方法

本研究では，教育サービス供給の変化を動態的に 把握するために，1965 年と 1995 年の 2 時点を比較 するが，この期間は岩手県における後期中等教育の 拡大期と位置づけることができる。例えば，岩手県 教育委員会は 1964 年に策定した「岩手県教育振興基 本計画」の中で, 高校進学率の向上を教育行政の重 要課題の 1 つとしている。そして，こうした計画が 契機となって高校の新設や既設高校の学級増が進 
み, 第 II 章の 1 節に示したように, 1965 年に 53.4\% であった岩手県の高校進学率は, 30 年後の 1995 年 には $97.4 \%$ に達している。また,この 30 年間は, 所 得水準や交通条件が改善されるとともに教育に対す る人々の意識が高まった時期でもあり，詳細は第 II 章の 1 節に記したと扔りである。したがって，教育 サービス供給の空間構造の変化を社会状況との関わ りで考察する上で，1965 年と 1995 年の比較は意味 があると考える。

なお，本研究では，高校のうち全日制課程のみを 分析の対象とする。これは，岩手県の高校在籍生徒 に占める全日制課程在籍生徒の比率が，1965 年は $87.6 \%, 1995$ 年は $98.5 \%$ であり ${ }^{7)}$, 両年次とも全日制 課程が高校教育の主体をなしていることによる。

4）進学行動の分析法

後述する第 IV 章では，高校の新規立地と交通条 件の改善という空間的な要素が，農山村地域に抢け る高校進学行動の変化にどのように影響したか，実 際の事例をもとに考察する。

事例とするのは，北上山地のほぼ中央部に位置す る岩泉ブロックである。同ブロックでは，1965 年以 降に高校の増設があり，また鉄道の延長や新規開業 など交通機関の整備も進んだ。これらは，学校施設 の立地パターンや交通条件の変化などといった空間 的要因と高校への進学行動の関係を観察する上で好 適な条件といえる。また，同ブロックでは，中学校 が主要な集落ごとに分散して立地する。そのため,実 際には各集落内に分散する生徒個々の居住地を一括 して中学校の立地点に置き換えて考えることで，集 落ごとの高校進学行動の把握が容易に行いうるとい う条件も備えている。

第 IV 章では，まず 1964 年〜1966 年と 1994 年 〜1996 年のそれぞれの期間について，岩泉ブロック 内の各中学校卒業者の高校別合格人数を把握し ${ }^{8)}$, 卒業者数に対する合格者数の比率を高校別に算出す ることで 1960 年代と 1990 年代の比較を行う。なお，
1964 年〜1966 年および 1994 年〜1996 年というよ うに 3 か年分を総合したデー夕を用いるとともに， 分校のデー夕はすべて本校に統合して集計し，それ でも 3 か年の卒業者が 10 人未満にしかならない中 学校は分析の対象から除外する。これは岩泉ブロッ クの中学校は小規模校が多く, サンプルが少なすぎ る事例が多数生ずることに対処するための措置であ る。

続いて，ブロック内の各集落から岩泉高校までの 通学距離と各集落の中学校卒業者に占める岩泉高校 への合格者比率の関係を, 1964 年〜1966 年, 1974 年 ～1976 年，1984 年〜1986 年，1994 年～1996 年とい う 4 つの時期に分けて検討する。各集落からの通学 距離は，各中学校から岩泉高校まで主要道路を利用 した際の距離とするが，これは地形図上においてキ ルビメーターで計測する。計測には, 50,000 分の 1 地 形図の 1974 年修正「岩泉」図幅と「田老」図幅掠よ び 1977 年修正「門」図幅と「大川」図幅を用いる。 な㧍，道路の整備によって実際の通学距離は年々短 縮される傾向にあるが，1960 年代以降，岩泉高校と 各中学校間の近接性の順位に変化がないことから, 便宜的に各年次とも通学距離は同一とみなすことと する。また，先の分析の場合と同様に，分校のデー 夕は本校に統合するとともに，3 か年の卒業者が 10 人未満の中学校は除外する。

5）資料

本研究で使用した主な資料は各高校の生徒数，学 科構成等については「学校一覧」(岩手県教育委員会 発行), 各高校の教員構成については「岩手県学事関 係職員録」(岩手教育会館発行)，岩泉ブロックにお ける中学卒業者の高校進学行動については各高校の 合格者名簿である。さらに，必要に応じて各種の統 計資料を参照し，岩手県内の高校に勤務する教員を 対象とする聞き取り調查を行った。 


\section{III. 岩手県の高等学校教育におけるサービス供 給の量的・質的地域差}

\section{1. 量的側面からみた地域差}

1) 学校数

学校教育の場合, 教育サービスの供給は学校の立 地地点において行われる。したがって，学校数の増 減はサービス供給量に直接的に影響するはずであ る。

第 1 表に各ブロックの学校数を示した。それによ ると, 岩手県全体で 1965 年に 75 校市った高校が, 1995 年には 97 校へと増加している (29.3\% 増)。こ れをブロック別にみると，北東地域に位置する 4 ブ ロック（宮古ブロック，岩泉ブロック，久慈ブロッ ク, 二戸ブロック）に扔いて，高校の増加数・増加 率がともに高い值となっている。このことは，北東 地域では，1964 年に岩手県教育委員会が策定した 「岩手県教育振興基本計画」の方針に沿って, 1965 年 以降に高校の新規立地が進んだことを示している。

一方，西部地域や南東地域のブロックでは，高校 の増加数や増加率が比較的低い值となっている。例 外的に，増加数が 4 校の盛岡ブロックや 2 校の水沢 ブロック, 増加率が $50 \%$ の遠野ブロックのような事 例も存在する。しかし，盛岡ブロックと水沢ブロッ クは増加率が県の平均值を下回り，遠野ブロックは 増加数が 1 校で, 結果的に西部地域や南東地域は北 東地域と比較して学校数の変化の程度が小さいとい える。こうしたことから, 西部地域や南東地域では, 1965 年の段階で高校の新規立地はほぼ終了してい たと判断できる。

以上のように，比較的早い時期に高校が立地した 地域がある一方で，近年になって高校の新設が進ん だ地域もあり，教育サービスの供給体制の整備時期 に地域差がみられる。

2）入学定員と「収容指数」

第 1 表に，ブロック別・年次別の収容指数を示し
た。それによると，県全体の収容指数は，1965 年に 0.49 であったものが 1995 年には 0.98 へと上昇して いることがわかる。ブロック別にみても，全てのブ ロックで值が上昇し, 30 年間にサービス供給量が相 対的に増大したことを示している。

また，第 2 図から収容指数のばらつきの程度をみ ると, 収容指数のレンジは 1965 年が $0.75,1995$ 年が 0.79 でほとんど変化がないことがわかる。この図か ら, 収容指数の地域差をみると, 1965 年と 1995 年の 両年次とも经盛岡 (第 2 図中の Mo), 北上 (同 $\mathrm{Ki}$ ), 一関（同 Ic）の 3 ブロックがサービス供給量の最も 多いグループを，岩手 (同 It)，西根 (同 Ns)，岩泉 (同 Ii)の 3 ブロックが最も少ないグループを，そし て残る 9 ブロックが中間的なグループを構成してい る。このように，岩手県に扔ける高校教育サービス は，ブロック間の格差構造をほぼそのまま維持する かたちで 1965 年からの 30 年間に相対的なサービス 供給量が増大したとみなしうる。

\section{2. 質的側面からみた地域差}

1）学科構成

第 1 表に,各ブロックの学科設置状況を示した。そ れによると，1965 年において商業系，工業系，農林 水産系の各専門学科がブロック内に全て揃うのは, 盛岡, 北上，一関，気仙，二戸の 5 ブロックのみで, 全体の 3 分の 1 のブロックにとどまっている。しか も，商業，工業，農林水産の各系統について独立校 が揃って立地するのは盛岡ブロックのみである。

ところが 1995 年になると，3 系統の専門学科が揃 うのは 9 ブロックに増える。また，専門学科の独立 校が 3 系統揃って立地するのは盛岡, 水沢, 宮古, 久 慈の 4 ブロックになっている。このように, 教育サー ビスの質的水準の向上がみられる。しかしその一方 で，岩手ブロックと西根ブロックのように，1965 年 と 1995 年の両年次ともに専門学科が一切設置され ていないブロックも存在する。また，岩泉ブロック では，1965 年に存在した専門学科が 1995 年になる 
第 1 表 全日制高校の立地，入学定員と中学卒業者数，学科設置状況

\begin{tabular}{|c|c|c|c|c|c|c|c|c|c|c|c|}
\hline \multirow{2}{*}{ ブロック名 } & \multirow{2}{*}{ 年 } & \multirow{2}{*}{$\begin{array}{l}\text { 学校 } \\
\text { 数 }\end{array}$} & \multirow{2}{*}{ 増減 } & \multirow{2}{*}{$\begin{array}{c}\text { 増減率 } \\
(\%)\end{array}$} & \multirow{2}{*}{$\begin{array}{l}\text { 高等学校 } \\
\text { 入学定員 }\end{array}$} & \multirow{2}{*}{$\begin{array}{c}\text { 中学 } \\
\text { 卒業者数 }\end{array}$} & \multirow{2}{*}{$\begin{array}{l}\text { 収容 } \\
\text { 指数 }\end{array}$} & \multicolumn{4}{|c|}{ 学科設置状況 } \\
\hline & & & & & & & & 普通科系 & 商業科系 & 工業科系 & 農水科系 \\
\hline \multirow{2}{*}{ 盛岡（Mo） } & 1965 & 17 & \multirow{2}{*}{4} & \multirow{2}{*}{23.5} & 5,065 & 7,128 & 0.71 & $\bigcirc$ & 0 & $\bigcirc$ & 0 \\
\hline & 1995 & 21 & & & 6,045 & 5,631 & 1.07 & 0 & 0 & 0 & 0 \\
\hline \multirow{2}{*}{ 岩手（It） } & 1965 & 2 & \multirow{2}{*}{0} & \multirow{2}{*}{0.0} & 240 & 1,156 & 0.21 & $\bigcirc$ & & & \\
\hline & 1995 & 2 & & & 289 & 443 & 0.65 & 0 & & & \\
\hline \multirow{2}{*}{ 西根（Ns） } & 1965 & 1 & \multirow{2}{*}{0} & \multirow{2}{*}{0.0} & 240 & 1,584 & 0.15 & 0 & & & \\
\hline & 1995 & 1 & & & 212 & 432 & 0.49 & 0 & & & \\
\hline \multirow{2}{*}{ 花巻（Ha） } & 1965 & 7 & \multirow{2}{*}{0} & \multirow{2}{*}{0.0} & 1,480 & 2,495 & 0.59 & $\bigcirc$ & 0 & & 0 \\
\hline & 1995 & 7 & & & 1,359 & 1,419 & 0.96 & 0 & 0 & $\triangle$ & 0 \\
\hline \multirow{2}{*}{ 北上（Ki） } & 1965 & 5 & \multirow{2}{*}{1} & \multirow{2}{*}{20.0} & 1,690 & 2,455 & 0.69 & 0 & $\triangle$ & 0 & $\bigcirc$ \\
\hline & 1995 & 6 & & & 1,552 & 1,318 & 1.18 & 0 & $\triangle$ & 0 & 0 \\
\hline \multirow{2}{*}{ 水沢（Mz） } & 1965 & 8 & \multirow{2}{*}{2} & 250 & 1,990 & 4,245 & 0.47 & 0 & 0 & & $\bigcirc$ \\
\hline & 1995 & 10 & & 25.0 & 1,842 & 2,050 & 0.90 & 0 & 0 & 0 & 0 \\
\hline 一関 (Ic) & 1965 & 6 & 1 & 167 & 2,270 & 2,556 & 0.89 & 0 & 0 & 0 & $\triangle$ \\
\hline 问 (IC) & 1995 & 7 & 1 & 10.1 & 1,611 & 1,262 & 1.28 & 0 & $\triangle$ & 0 & 0 \\
\hline 東幋井 (Hi) & 1965 & 4 & 1 & 25.0 & 860 & 2,557 & 0.34 & 0 & 0 & & $\triangle$ \\
\hline 告开 (111) & 1995 & 5 & 1 & 20.0 & 640 & 878 & 0.73 & 0 & 0 & & 0 \\
\hline$(\mathrm{Ke})$ & 1965 & 6 & 0 & 00 & 1,110 & 2,630 & 0.42 & $\bigcirc$ & $\triangle$ & $\bigcirc$ & 0 \\
\hline x(i山 (ne) & 1995 & 6 & 0 & 0.0 & 1,040 & 1,093 & 0.95 & 0 & $\triangle$ & 0 & 0 \\
\hline 遠野（To） & 1965 & 2 & 1 & 50.0 & 460 & 1,282 & 0.36 & 0 & $\triangle$ & & $\bigcirc$ \\
\hline 还玨 (10) & 1995 & 3 & 1 & 50.0 & 440 & 478 & 0.92 & 0 & $\triangle$ & & 0 \\
\hline 釡石 (Ka) & 1965 & 5 & 0 & 0.0 & 1,480 & 2,875 & 0.51 & 0 & $\bigcirc$ & 0 & \\
\hline 金石 (nd) & 1995 & 5 & 0 & 0.0 & 880 & 903 & 0.97 & 0 & 0 & 0 & \\
\hline 宮古 (Mv) & 1965 & 4 & 3 & 750 & 1,040 & 2,988 & 0.35 & 0 & 0 & & 0 \\
\hline 呂口 (IVy) & 1995 & 7 & 3 & 75.0 & 1,160 & 1,260 & 0.92 & 0 & 0 & 0 & 0 \\
\hline (Ji) & 1965 & 1 & 2 & 2000 & 140 & 992 & 0.14 & 0 & & & $\triangle$ \\
\hline (11) & 1995 & 3 & 2 & 200.0 & 200 & 284 & 0.70 & 0 & & & \\
\hline 久兹 $(\mathrm{Ku})$ & 1965 & 3 & 5 & 1667 & 610 & 2,366 & 0.26 & 0 & & $\triangle$ & 0 \\
\hline 人愁 (Ku) & 1995 & 8 & 3 & 100.1 & 960 & 1,112 & 0.86 & 0 & 0 & 0 & 0 \\
\hline$(\mathrm{Nn})$ & 1965 & 4 & 2 & 500 & 930 & 2,700 & 0.34 & 0 & $\triangle$ & 0 & $\triangle$ \\
\hline$(\mathrm{Nn})$ & 1995 & 6 & 2 & 50.0 & 920 & 1,020 & 0.90 & 0 & $\triangle$ & 0 & $\triangle$ \\
\hline & 1965 & 75 & 22 & 293 & 19,605 & 40,009 & 0.49 & - & - & - & - \\
\hline & 1995 & 97 & 26 & 29.3 & 19,150 & 19,583 & 0.98 & - & - & - & - \\
\hline
\end{tabular}

(「学校一覽」,「岩手県統計年鑑」「岩手年鑑」および聞き取り調査により作成)

「学校数」は，公立高校と私立高校および本校と分校を合計した值で示している。

「収容指数」は，当該ブロックにおける公立と私立を合計した高等学校の入学定員を中学卒業者数で除した值で

ある。

「学科設置状況」欄において，○印は商業高校や工業高校や農業高校といった当該系統学科の独立校が立地する ことを示す。வ印は普通高校に設置された商業科や農業科のように，当該系統学科が別系統学科を主とする学 校に併設されて存在していることを示す。なお，同一ブロック内に専門学科の独立校が立地する事例と別系統 学科の学校に併設される事例が並存する場合は，○印のみを記している。

「ブロック名」欄のアルファベット記号は第 1 図と共通である。 


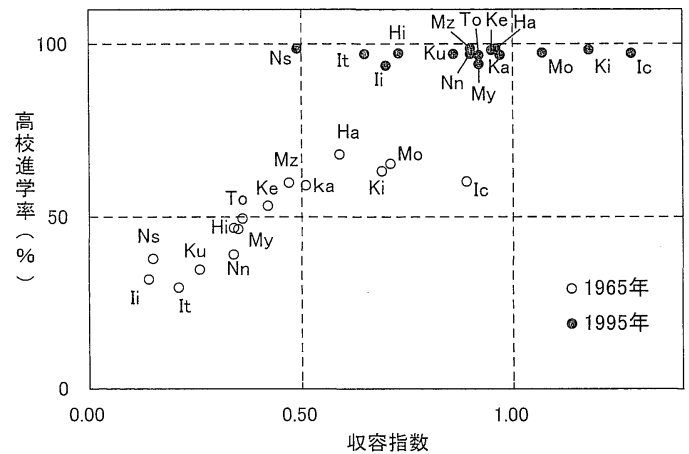

第 2 図 全日制高校の収容指数と高校進学率の関係 高校進学率は中学卒業者に対する高校進学 者の比率で，「岩手県統計年鑑」による。収 容指数の值は第 1 表と同じである。 図中のアルファベット記号はブロック名を 示し，第 1 図および第 1 表と共通である。

と廃止されている。

このように，サービスが低い水準で据え置かれて いる地域やサービス水準が切り下げられた地域もあ り，全体的にみると教育サービスの質的地域差は拡 大傾向にあるといえる。

2）学校規模

第 2 表は, 1965 年と 1995 年における全日制高校 の生徒数別学校数とその比率を示している。高校教 員からの聞き取りによると，岩手県では概ね生徒数 900 人を境に大規模校と中規模校をまた生徒数 300 人を境に中規模校と小規模校を区別する傾向がある という。そこで，第 2 表では新たに生徒数 600 人を 境とする中規模校の小区分を設け，学校規模を 4 つ のカテゴリーに区分している。これによると，1965 年当時，生徒数 600 人以上の学校が過半数を占めて いたものが, 1995 年になると逆に生徒数 599 人以下 の学校が過半数となり，全体的に高校の小規模化が 進んでいる。

ところで，第 2 表において最も規模が小さいのが 生徒数 299 人以下というカテゴリーである。こうし た規模の高校になると，第 II 章の 2 節に記したよう な小規模校としての弊害が顕著にあらわれると予想
第 2 表 全日制高校の生徒数別学校数

\begin{tabular}{|c|c|c|}
\hline 生徒数 & 1965 年 & 1995 年 \\
\hline 900 人以上 & 23 校（30.7\%） & 19 校（19.6\%） \\
\hline $600 \sim 899$ 人 & 26 校 ( $34.7 \%)$ & 21 校（ $21.6 \%)$ \\
\hline $300 \sim 599$ 人 & 19 校（25.3\%） & 40 校（ $41.2 \%)$ \\
\hline 299 人以下 & 7 校（ $9.3 \%)$ & 17 校（17.5\%） \\
\hline 合 計 & 75 校 $(100.0 \%)$ & 97 校 $(100.0 \%)$ \\
\hline
\end{tabular}

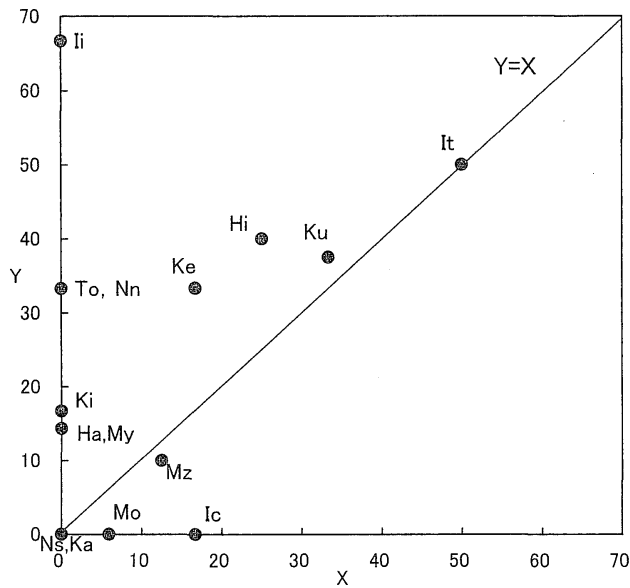

第 3 図 生徒数 299 人以下の全日制高校の比率 X : 1965 年の生徒数 299 人以下の全日制 高校比率（\%)

Y : 1995 年の生徒数 299 人以下の全日制 高校比率（\%)

図中のアルファベット記号はブロック名を 示し，第 1 図および第 1 表と共通である。 「学校一覽」により作成。

される。したがって, 生徒数 299 人以下の高校の比 率の増減は，サービスの質の変化を端的に示す指標 とみなしうる。

そこで，第 3 図に各ブロックにおける生徒数 299 人以下の学校比率の増減を示した。この図において， $\mathrm{Y}=\mathrm{X}$ の直線より下方にプロットされていれば， 1965 年からの 30 年間に生徒数 299 人以下の学校の 比率が低下したことになるのであるが，それに該当 するのは盛岡 (第 3 図中の Mo)，水沢 (同 $\mathrm{Mz}$ )，一 関（同 Ic）の 3 ブロックのみである。 $\mathrm{Y}=\mathrm{X}$ の線上 
にプロットされる岩手 (同 It)，西根 (同 Ns)，釜石 (同 Ka) の 3 ブロックは状況に変化がない。残る 9 ブロックは $\mathrm{Y}=\mathrm{X}$ の直線より上方にプロットされ, 生徒数 299 人以下の学校の比率が増加している。中 でも，東磐井(同 $\mathrm{Hi})$, 気仙 (同 $\mathrm{Ke}$ ), 遠野(同 To), 岩泉 (同 $\mathrm{Ii})$, 久慈 (同 $\mathrm{Ku}$ ), 二戸 (同 $\mathrm{Nn}$ ) の各ブ ロックは, 1995 年の時点で生徒数 299 人以下の学校 の比率が 30\% を超えており，これに 1965 年と 1995 年の両年次とも $50 \%$ であった岩手ブロック (同 It) を加えると，県の北東地域や南東地域に扔てて教育 サービスの質的水準の低下傾向が顕著といえる。

3）教員の配置

i）教職経験年数別教員構成比率

第 4 図に, 各ブロックの公立高校教員について 1965 年と 1995 年の経験年数別の構成比率を示し た ${ }^{9)}$ 。これによると, 全体的に 1965 年よりも 1995 年 の方が, 経験年数 21 年以上のベテラン教員の比率が 高くなっており, 教員の高齢化が進んでいる。その 中でも, 西部地域の各ブロックでは, 経験年数 11 年 以上の教員が両年次とも過半数を占めている。特に， 1995 年には経験年数 21 年以上の教員だけで過半数 を超えて抢り,最も高齢化の著しい地域といえる。対 照的に, 宮古, 岩泉, 久慈の各ブロックでは, 両年 次とも経験年数 10 年以下の教員が過半数を占め,こ の 3 ブロックに岩手, 気仙, 釜石, 二戸の各ブロッ クを加えた北東地域おょび南東地域で経験年数 10 年以下の若手教員が比較的多くなっている。

ベテラン教員が多数を占める状況と若手教員が多 数を占める状況のいずれを質的に良好な教育サービ スとみなすかは,一概に判定できるものではない。し かし, 教員の構成に地域的な偏りがあり, そのパター ンは 1965 年から 1995 年にかけてほとんど変化して いないことは明らかである。以上のように，地域に よって教員構成に偏りが生ずるのは，(1) 西部地域 と比較した時, 北東地域や南東地域は生活条件が劣 り，教員の間ではそうした地域への赴任を忌避する

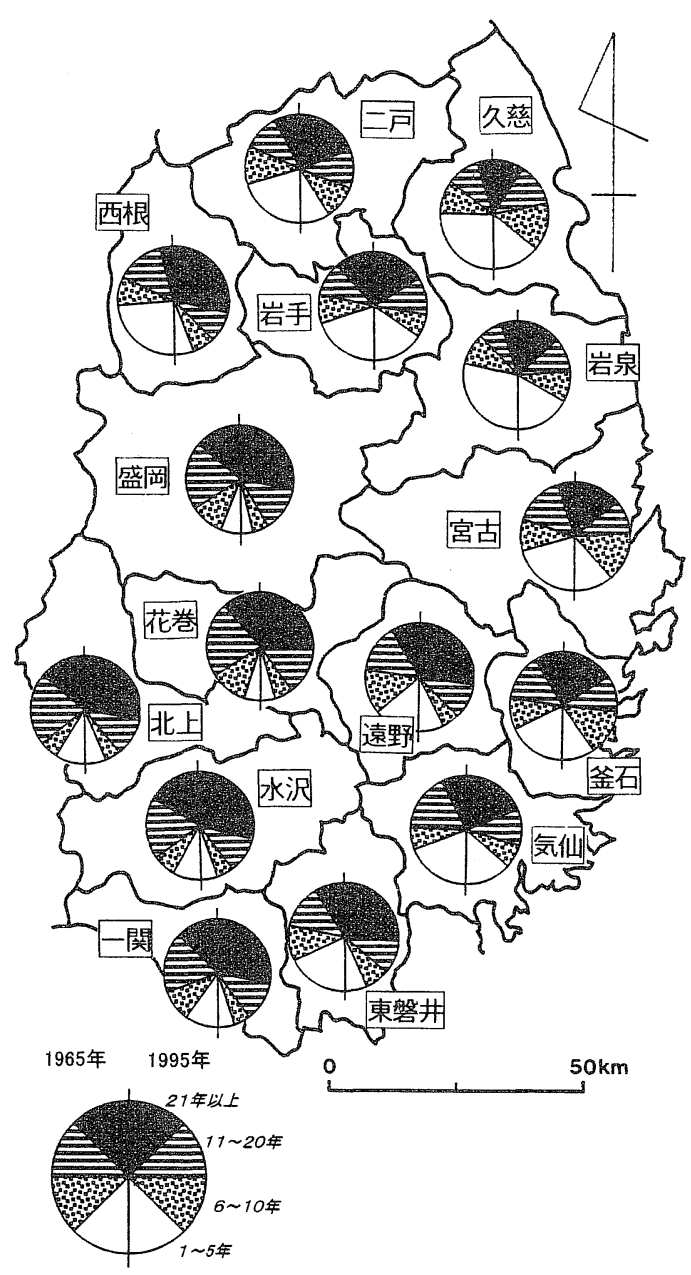

第 4 図 公立全日制高校の教職経験年数別教員構成 「岩手県学事関係職員録」により公立全日制 高校に勤務する教諭と常勤講師を対象に集 計した。図中の枠内の地名はブロック名を 示している。

傾向が強い ${ }^{10)}$, (2) 岩手県の教員は盛岡ブロック以 南の西部地域の出身者が多い ${ }^{11)}$, (3) 西部地域に生 活基盤を有する教員であっても，退職までに最低一 度は北東地域や南東地域での勤務を経験させるとす る教育行政当局の方針があることから，若いうちに 北東地域や南東地域勤務のノルマをクリアしようと 考える教員が多い ${ }^{12)}$ ，といった諸事情が背景にある と考えられる。 
ところで, 西根, 遠野, 東磐井の 3 ブロックは，い ずれも 1965 年には経験年数 10 年以下の教員が過半 数を占め, 県の北東地域や南東地域と同様の傾向を 示していた。しかし，1995 年になると，いずれも経 験年数 21 年以上の教員が過半数を占めるようにな り，西部地域と同じタイプになっている。これは， 1965 年以降, 道路が整備されて自家用車が普及した ために，これら 3 ブロックが西部地域から通勤可能 な圏域となり，元々ベテラン教員の比率の高かった 西部地域の高校から西根，遠野，東磐井ブロックの 高校へ赴任する事例が増加したためと考元られる。 現職の高校教員からの聞き取りによると，今日，西 根ブロックは盛岡市周辺から, 遠野ブロックは花巻 市周辺から，東磐井ブロックは一関市および水沢市 周辺から通勤可能な圈域と認識されているという。

ii）同一校在職年数別教員構成比率

第 5 図に, 花巻, 東磐井, 久慈の 3 ブロックを取 り上げ,各ブロックの公立高校教員について 1965 年 と 1995 年の年度末時点での同一校在職年数を示し た ${ }^{13)}$ 。なお, 先の検討にもとづき, 1965 年と 1995 年 の両年次ともべテラン教員が多数を占める地域の事 例として花巻ブロック, 両年次とも若手教員が多数 を占める地域の事例として久慈ブロック，1965 年の 時点では若手教員主体の構成であったものが 1995 年にはべテラン教員主体の構成へと変化した地域の 事例として東磐井ブロックを選択した。また，全日 制高校生徒の在籍期間が原則として 3 年であること から, 在職 3 年以下の教員を短期在職者, 在職 7 年 以上の教員を長期在職者として，ここでは短期在職 者が少なく長期在職者が多い状態を質的に良好な教 育サービスとみなすことにした。第 5 図では横軸が 在職 3 年以下の教員比率, 縦軸が在職 7 年以上の教 員比率になっており，プロット位置が図の左上であ れば良好な教育サービスが提供されていることを意 味する。

この図によると，供給されるサービスの質的水準

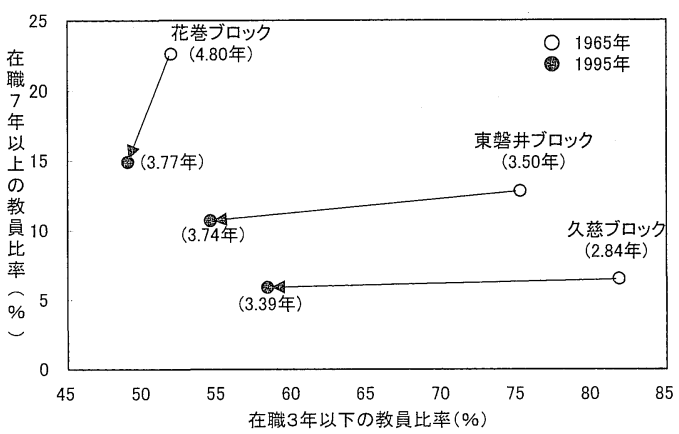

第 5 図 花巻ブロック・東磐井ブロック・久慈ブロッ クに抢ける同一校在職年数別教員比率 図中の括弧内は同一校在職年数の平均值を 示す。

「岩手県学事関係職員録」により作成。

の高さは，1965 年と 1995 年の両年次とも花巻ブ ロック，東磐井ブロック，久慈ブロックの順となっ ていることがわかる。しかし, 1965 年以降の 30 年間 に，花巻ブロックでは長期在職者比率が，東磐井ブ ロックと久慈ブロックでは短期在職者比率がそれぞ れ大幅に低下したため，ブロック間の格差は縮小し ている。このことは，図中に示した平均在職年数の 值からも窺うことができる。以上の結果は，1965 年 以降，一貫して教員の定着性に地域差が存在してい るものの，時間の経過につれて格差は解消されつつ あることを示している。

なお，第 4 図に扔いて 1965 年と 1995 年で異なる タイプに属するとされた東磐井ブロックの第 5 図に おけるプロット位置をみると，1965 年には久慈ブ ロックの位置に近かったものが 1995 年には久慈ブ ロックと花巻ブロックのほほ中間にプロットされて いる。平均在職年数の值では，1965 年は久慈ブロッ クに近かったものが 1995 年には花巻ブロックとほ とんど同じ值となり，ベテラン教員の構成比率が大 幅に上昇するとともに教員の定着性が花巻ブロック の水準に近づいたということができる。

以上のように，第 4 図と第 5 図から，西部地域で は，経験豊富でしかも同一校での在職期間も長いこ 
とから各学校の生徒や学校を取り巻く地域社会の状 況をよく理解した教員が主体となって日常の教育活 動が展開されているのに対し, その他の地域では, 教 員の経験が浅くかつ定着性も悪いという大まかな構 図を読み取ることができる。ただし，前述のように 教員の定着性の地域格差は縮小傾向にあり，また東 磐井ブロックのように交通条件の改善によって教員 の定着性が大幅に改善した地域も存在する。

\section{IV. 岩泉ブロックにおける高等学校進学行動の 地域差と進学機会の空間分布}

第 III 章でとりあげた第 2 図は，各ブロックの収 容指数だけでなく，高校進学率についても示してい

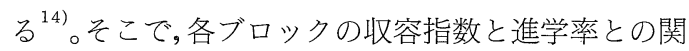
係をみるとまず 1965 年の段階において収容指数と 高校進学率は強い正の相関を持っていることがわか $る^{15)}$ 。ところが, 1995 年になると収容指数の值に関 係なくいずれのブロックも $100 \%$ に近い高校進学率 を示すようになり，収容指数と高校進学率とのあい だに有意な相関を見出すことができなくなる。特に， 収容指数 1.00 未満のブロック,つまり地元の高校だ けでは地元の中学卒業生を収容しきれないブロック でも, 進学率は収容指数 1.00 以上のブロックと大差 がないという状況が生じている。

このように高校進学率が上昇したことの背景とし ては，特に北東地域や南東地域のような山間に小集 落が点在する傾向の強い地域の場合，高校の新設や 交通条件の改善によって通学可能な高校が増えたこ とが大きく影響したと推測される。

そこで本章では，高校の新規立地や交通条件の改 善といった空間的な要素が農山村地域に扔ける高校 進学率の上昇にどのように影響しているか，岩泉ブ ロックを事例として考察する。

\section{1. 高校の新設と交通条件の改善が高校進学行動 に及ぼす影響}

第6 図は, 岩泉ブロックに抢ける中学卒業者の全
日制高校合格状況を示したものである。

このうち, 第 6 図 A は 1964 年〜1966 年の状況を 示している。当時の岩泉ブロック内の全日制高校は 岩泉高校のみである。また，交通条件が鱼く，岩泉 ブロックから他のブロックの高校へ通学することは ほぼ不可能な状況であった。そのため，岩泉ブロッ ク内のいずれの中学校も, 全日制高校への進学者の 大部分が岩泉高校への進学者によって占められてい る。そうしたことから，同じ岩泉ブロック内の中学 校であっても, 岩泉高校へのアクセスの良否に対応 するように，全日制高校進学率に大きな差が生じて いる。

これに対して，1994 年〜1996 年の状況を示す第 6 図 B では，岩泉高校以外に岩泉高校の分校である小 川校と田野畑校が全日制高校となっている ${ }^{16)}$ 。その ため, 小川中学校(第 6 図記号 e) と田野畑中学校(同 1) の卒業生にとっては，それぞれ小川校と田野畑校 が第 1 位の進学先となっている。また，前述のよう に 1984 年に太平洋沿岸に鉄道が開通し,盛岡市およ び久慈市方面に通じる道路の整備が進んだこともあ り, 特に小本中学校 (第 6 図記号 $\mathrm{k}$ ) と田野畑中学校 (同 1) では宮古ブロック方面へ，安家中学校（同 h) では久慈ブロック方面への進学が主要な選択肢と なっている。一方，大川中学校 (第 6 図記号 c) と釜 津田中学校（同 d）は，1990 年代においても自宅か ら通学可能な高校は岩泉高校しかない。しかし, 前 述のように, 1972 年に当時の国鉄岩泉線の終点が岩 泉高校の近くまで延長されたことで岩泉高校への通 学が容易になり，1960 年代よりも岩泉高校への進学 者比率が増えている。

このように, 1990 年代になると, 岩泉高校へのア クセス条件に恵まれなかった地域においてもその後 の高校の新設や交通条件の改善によって岩泉高校以 外の新たな選択肢が加わり，同時に岩泉高校自体へ の通学条件も改善され，以前より高校進学が容易に なっている。そして，ブロック内の高校進学率の地 


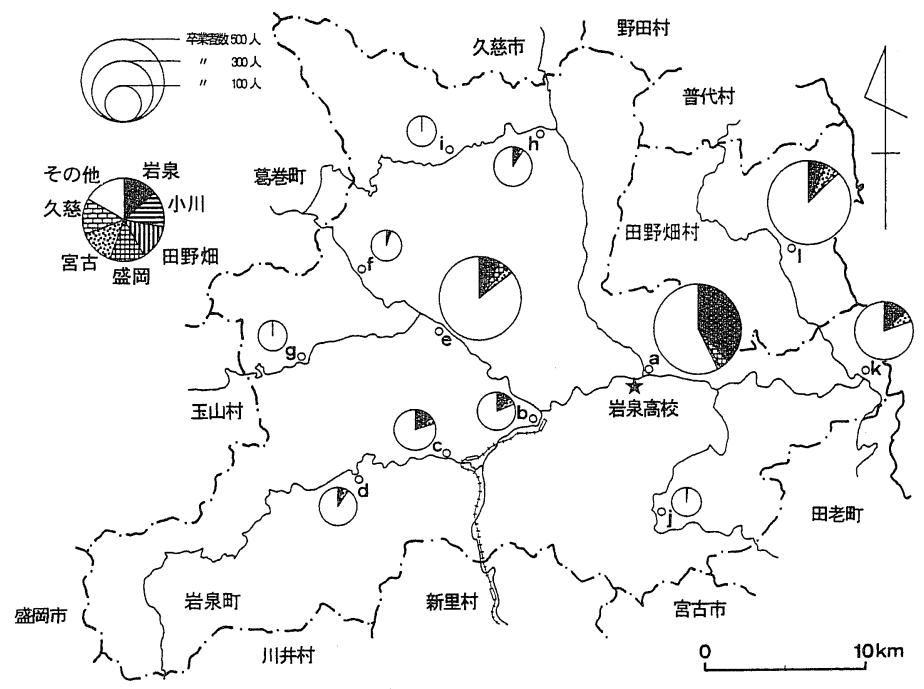

A. 1964 年 1966 年

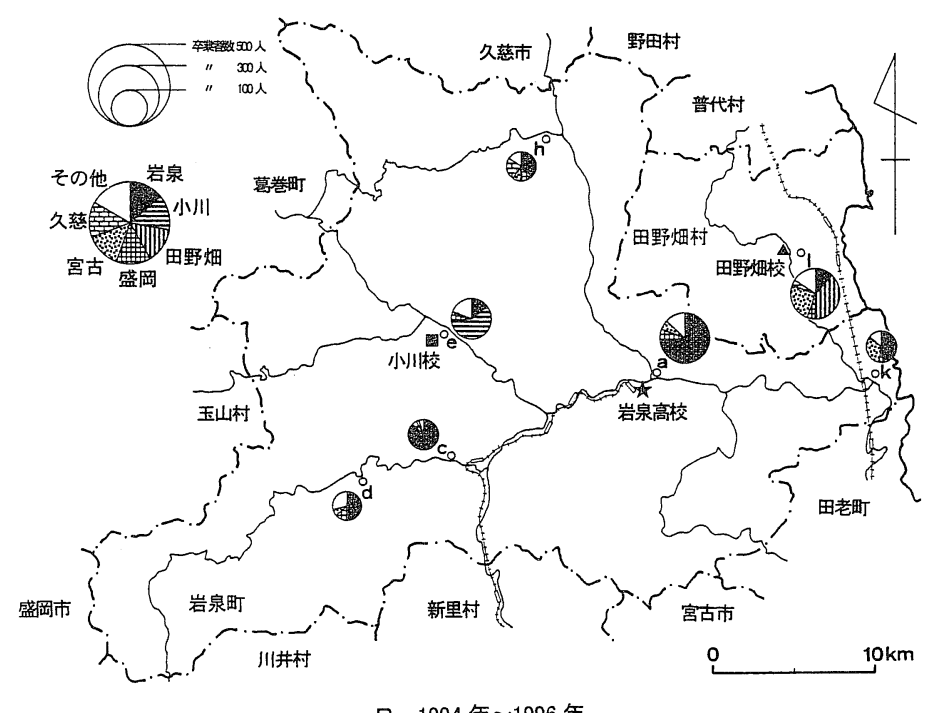

B. 1994 年 1996 年

第 6 図 岩泉ブロック内の中学校における卒業者の高校（公立全日制）別合格者比率 ○: 中学校の所在地, 女: 岩泉高校, 岩泉高校小川校, $\Delta$ : 岩泉高校田野畑校 $\sim m$ : 主要道路, 一一: 鉄道

「岩泉」は岩泉高校本校，「小川」は岩泉高校小川校，「田野畑」は岩泉高校田野畑校，「盛岡」，「宮古」， 「久慈」はそれぞれ各ブロック内の高校。「その他」は公立全日制以外の高校と非進学者。

〈中学校名〉 $\mathrm{a}$ : 岩泉, $\mathrm{b}$ : 浅内, $\mathrm{c}$ : 大川, $\mathrm{d}$ : 釜津田, e : 小川, $\mathrm{f}$ : 国見, $\mathrm{g}$ : 権現, $\mathrm{h}$ : 安家，i:大 平, $\mathrm{j}$ : 有芸, $\mathrm{k}$ : 小本, 1 : 田野畑

各高校の合格者名簿および「学校一覧」により作成。 


\section{A. 大川・釜㴋田方面}

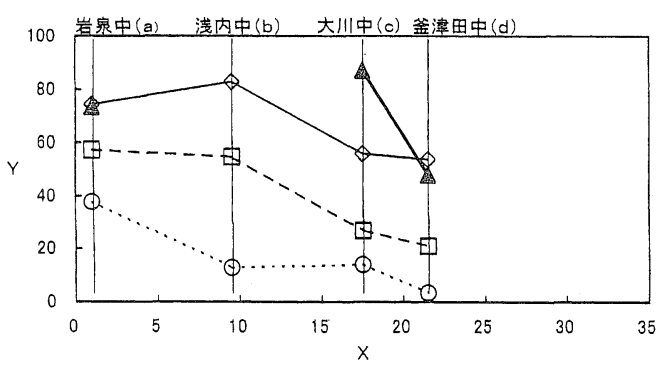

C. 安家方面
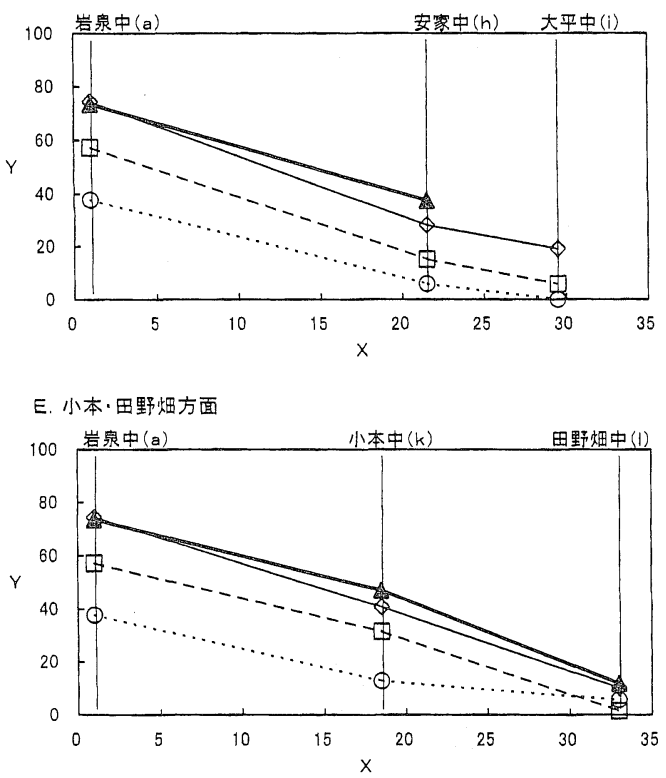

B. 小川方面

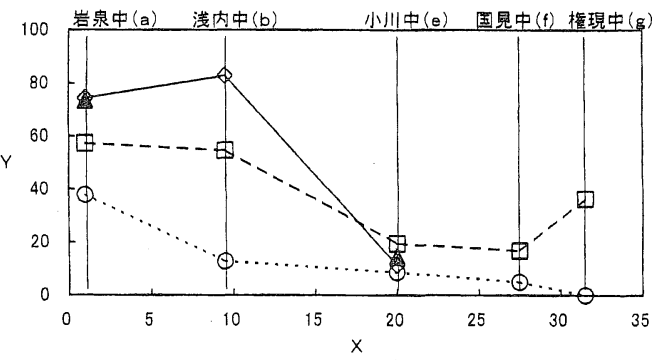

D. 有芸方面

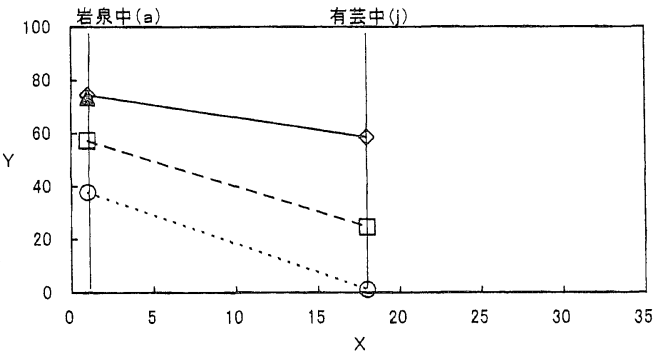

X: 各中学校から岩泉高校までの距離 $(\mathrm{km})$ $Y:$ 岩泉高校合格者比率 $(\%)$

…⒈1964年〜1966年

一も-1974年〜1976年

○-1984年〜1986年

一这-1994年〜1996年

第 7 図 岩泉高校からの距離と岩泉高校合格者比率の関係 $\mathrm{a} \sim 1$ は第 6 図と同じ。

域差が 1964 年〜1966 年当時と比較して縮小し，岩 泉ブロック全体の高校進学率が上昇している。

\section{2. 通学距離と合格者比率の関係}

第 7 図は，1964 年～1966 年，1974 年～1976 年, 1984 年〜1986 年, 1994 年〜1996 年という 4 つの時 期について，岩泉ブロック内の各中学校から岩泉高 校までの通学距離と各中学校の卒業者に占める岩泉 高校合格者の比率との関係をあらわしており，岩泉 高校に至る通学ルートの方向性により，A〜Eまで の 5 つのグラフに分けて示している。

これらの図が示すように，若干の例外はあるもの
の, 1960 年代から 1980 年代にかけて, 各中学校とも 岩泉高校への合格者比率を増加させている。そして， 各年代とも岩泉高校までの通学距離に反比例して合 格者比率が低下する傾向がみられる。一方，1990 年 代については, 岩泉高校合格者比率が 1980 年代とほ ぼ同じという例が多い。これは，第 II 章の 1 節に記 したように，岩手県の高校進学率が 1980 年に 90\% を突破し，上昇を続けてきた高校進学率がこの頃に ほぼ上限に達したことが背景にあると考えられる。 ただ，1990 年代についても，通学距離とともに合格 者比率が我減する傾向を確認できる。 


\section{IV. ま と め}

本研究では，岩手県を事例として高校教育に関わ るサービスの供給と進学行動について検討した。得 られた知見を以下に列挙する。

(1) 高校における教育サービスの供給体制が整備 される時期に地域差がみられる。すなうち，県の西 部および南東地域では 1960 年代半ばには高校の新 規の立地がほほ終了していたのに対し，北東地域で は 1960 年代以降に高校の新設が進んだ（第 1 表）。

(2) 高校の入学定員を中学卒業者数で除した収容 指数によって教育サービス供給の量的な地域差の把 握を試みた。その結果, 1965 年からの 30 年間に全て のブロックで収容指数が増大したものの，全体的に 西部地域で指数が高く北東地域で低いという地域差 の構造が一貫して存在することが明らかとなった (第 1 表，第 2 図)。

(3) 専門学科の設置状況については，全体的に サービス水準が向上しているものの，サービス水準 が低い状態で据え置かれている地域やサービス水準 が切り下げられた地域もあり，地域差が拡大してい る(第 1 表)。学校規模の面については, 全体的に小 規模化が進んでいる(第 2 表)。特に, 北東および南 東地域では, 生徒数が 300 人に満たないような学校 の比率が増えており，サービス水準の低下が顕著で ある(第 3 図)。教員構成の面でも，西部地域にべう ラン教員，その他の地域に若手教員が集中する傾向 がいずれの年次でもみられ(第 4 図)，しかもべテラ ン教員の多い地域は同一校在職年数も長くなる傾向 にある(第 5 図)。以上のように，教育サービスの供 給には質的な地域差も存在する。

(4) 1965 年当時, 各地域の収容指数と高校進学率 の間には強い正の相関がみられた。しかし，その後 の全県的な所得水準の向上や縁辺地域での高校の新 設，および交通条件の改善などによって進学率の地 域差が縮小し, 1995 年になると収容指数と進学率の
関連性は消滅した（第 2 図）。

(5) 岩泉ブロックを事例として受験生の居住地と 進学行動の関係を検討した。まず, 1960 年代には,ブ ロック内に扔いて，岩泉高校が立地する地区とそれ 以外の地区との間で高校進学率に大きな格差が生じ ていたが，1990 年代になるとそうした格差は縮小 し，ブロック全体の高校進学率も上昇している（第 6 図)。また, 岩泉高校への進学率は, ブロック内の いずれの地区でも時代とともにほほ一貫して上昇し ているが，各年代とも岩泉高校までの距離に反比例 することが確認された(第 7 図)。以上から，岩泉ブ ロックの高校進学率が上昇し，ブロック内に沶ける 地域差が解消されてゆく過程は，次のように説明で きる。まず，交通条件に恵まれなかった 1960 年代， ブロック内に㧍いて岩泉高校から遠い縁辺地域で は, 通学可能な範囲に高校がなく, そのために高校 進学率が極めて低い值となっていた。やがて，所得 水準の向上などから進学意欲が高まり，同時に交通 条件の改善もなされ，ブロックの縁辺地域から岩泉 高校に進学する者が増加した。しかし，それでも岩 泉高校への通学が困難な地域はいくつか残された が，そうした地域では，近接地に高校が新設された り，交通条件の改善によってブロック外の高校への アクセス条件が向上したことから岩泉高校以外の高 校へ進学するようになり，結果的に，ブロック内の ほぼ全域で高校教育サービスを受容することが可能 になったのである。

ところで，住民に供給される教育サービスの量や 質は，本研究で取り上げた指標以外にも多様な指標 によってその水準を測りうると考えられる。そうい う意味に扔いて，本研究は教育サービスの多様な側 面の一部について論じたに過ぎない。また，受験生 の居住地と進学行動の関連性について, 本研究では 人口希薄地域の事例を検討したが，比較的狭い範囲 に学校や居住地が複雑に分布する都市内部地域にお いては本研究の結果とは異なる進学行動パターンが 
観察される可能性もある。さらに，公共サービスの 地域配分について，各地域の人々のニーズに応じた サービス配分を理想と考える「地域的公正」の概念 ${ }^{17)}$ に照らすなら，本研究は教育に対する地域住民の ニーズの検討を欠いている。従って，本研究で明ら かとなった教育サービスの地域差を社会的不公正と みなしうるかという点は不明確なままである。以上 の諸点は, 今後の実証研究において検討すべき事項 と考える。

\section{謝辞}

本稿の作成にあたり，岩手大学人文社会科学部の杉浦 直先生, 高橋宏一先生に御指導いただきました。また, 岩 手大学教育学部の遠藤匡俊先生からは有益な御助言をい ただきました。以上の先生方に心より感謝申し上げます。 本研究は, 1998 年 1 月, 岩手大学大学院人文社会科学 研究科偍出した修士論文の一部に加筆修正を施したも のであり, その骨子は 2000 年度東北地理学会春季学術大 会において発表した。

(2001年 10 月 24 日 受理)

\section{注}

1）浮田（1988）は，自宅から通学可能な範囲に高校 が立地しない地域が存在することを明らかにして いる。

2）「学校基本調査」(文部省）による。

3）岩手県教育委員会編（1982）においても，主に 1960 年代以前の状況を述べた部分で，保護者の意 識の低さが教育の普及や学力の向上を妨げていた との記述が随所になされている。

4）後藤（1980）と木村（1994）は，いずれも国勢調 查報告をもとに岩手県内に扮ける通勤流動を分析 している。このうち, 後藤は 1965 年と 1975 年の 2 時点を, 木村は後藤の手法を踏襲しながら 1980 年, 1985 年, 1990 年の 3 時点を分析の対象としている。

5）石郷岡 (1999） は，1990 年度在籍生徒の国公立大 学合格率が一定の水準以上にある岩手県内の高校 15 校を「上位校」としているが，そのうち 13 校は 生徒数 900 人以上の大規模校である。また, 岩手県 高等学校体育連盟 (2000, pp. 13-18) によると, 1965 年から 1995 年までの岩手県高等学校総合体育大会 (インターハイ予選) に抢ける団体種目の優勝校は
延べ 1,813 校であるが，このうち 868 校 $(47.9 \%)$ が 生徒数 900 人以上の学校によって占められ, 生徒数 299 人以下の学校の優勝は 28 校（1.5\%）に過ぎな w。

6）例えば，花巻ブロック内の公立高校（1965 年 5 校, 1995 年 6 校) には, 前掲 5) で触れた上位校 15 校のうちの 1 校が含まれる。当該高校 (以後 $\lceil\mathrm{H}$ 高 校」とする) とブロック内の他の公立高校について, 後揭 13）に示す方法によって教諭と常勤講師の平 均在職年数を算出すると, 1965 年は $\mathrm{H}$ 高校 5.10 年 に対して他の公立高校 4.72 年, 1995 年は $\mathrm{H}$ 高校 4. 11 年に対して他の公立高校 3.67 年となり, 高等教 育機関への進学について高い実績を有する高校は, 教員の在職年数が長くなる傾向にある。

7）「学校一覧」(岩手県教育委員会発行)による。

8）実際には, 各高校の発表をもとにして新聞に揭載 される合格者名簿を資料として用いた。な扝，高校 合格者の個人名と出身中学校名のデー夕が揃って 得られるのは 1964 年から 1996 年までの期間に限 られる。こうした資料上の制約も，第 IV 章での分 析年次の選択理由となっている。

9）岩手県の場合, 教員個々の年齢や教職経験年数を 示す資料は存在しない。ただ,「岩手県学事関係職員 録 (以後「職員録」とする)」(岩手教育会館発行) に は, 各学校の教職員について氏名, 職名, 最終学歴 修了年等の記載がある。そこで, 正確な教職経験年 数とは誤差が生じる事例も含まれるが,「1965 年度 版職員録」と「1995 年度版職員録」によって各教員 の最終学歷修了年からの経過年数を把握し, それを 教職経験年数とみなすこととした。な扔,管理職や 非常勤講師は集計の対象から除外している。また, 私立高校も, 公立高校の退職教員を雇用するなど公 立高校とは異なった人事体系を持ち, 公立高校との 単純な比較が難しいことから集計の対象としてい ない。よって, 集計の対象とされたのは公立高校の 教諭と常勤講師であり, 総数は 1965 年が 1,932 名, 1995 年が 2,941 名である。

10）岩手県教育委員会編（1982，pp. 1286-1290, 13161321）および高校の現職教員からの聞き取りによ る。

11）岩手県教育委員会編 (1982，pp. 654-662）による。

12）岩手県教育委員会編（1982，pp. 1143-1144）およ び高校の現職教員からの聞き取りによる。

13）個々の教員の同一校在職年数は, 各年度末時点で の当該勤務校における通算在職年数であらわす。具 
体的には,「岩手県学事関係職員録 (以後「職員録」 とする)」(岩手教育会館発行）をもとに，例えば 1965 年については「1965 年度版職員録」に記載され ている教員について「1964 年度版職員録」「1963 年 度版職員録」…‥順に同一校に在職するか否かを 名前を照合することによって確認し, 教員個々の在 職年数の確定を行った。なお，前掲 9) と同様, 管理 職や非常勤講師および私立高校教員は集計の対象 としていない。したがって, 最終的に, 1965 年は花 巻ブロック 133 名, 東磐井ブロック 109 名, 久慈ブ ロック 77 名, 1995 年は花巻ブロック 202 名, 東磐 井ブロック 121 名, 久慈ブロック 187 名を集計し た。

14）第 1 表に示したとおり, 収容指数は中学卒業者数 に対する全日制高校の入学定員の比率である。一 方, 高校進学率は, 資料上の制約加ら全日制高校の 他に定時制高校や工業高等専門学校への進学者も 含んだ值となっている。しかし, 第 II 章の 2 節で述 べたように，1965 年と 1995 年のいずれの年次にお いても高校在籍者の大部分が全日制課程在籍者で 占められており,工業高等専門学校への進学も全体 からみれば極めて少ない。ゆえに, 高校進学率は, 全 日制高校への進学率の值として代用し得ると判断 した。

15）相関係数は +0.87 (危険率 $1 \%$ で有意), 回帰式は $\mathrm{Y}=50.96 \mathrm{X}+27.76$ となる。

16）小川校と田野畑校は元々定時制課程であったが， 田野畑校は 1971 年の新入生から, 小川校は1975 年 の新入生から全日制課程に移行した。

17）ピンチ (1990, pp. 48)によると，「地域的公正」の 概念は, 各人のニーズに応じて各人にサービスを配 分することを重視する「社会的公正」概念を空間へ 拡張したものあり，社会福祉行政の分野における Davies（1968）の提唱にはじまる。なお，わが国に おいて地域的公正概念を用いて公共サービスの配 分を検討した地理学的研究としては, 高歯者福祉 サービスのニーズと供給の関係を検討した杉浦 (1997）があげられる。

\section{文献}

青野壽郎・尾留川正平編（1975）：日本地誌 第 3 巻 (東北地方総論・青森県・岩手県・秋田県)。二宮 畫店.

石郷岡信行（1991）：岩手県における公立小学校の
統廃合に関する地理学的考察。東北地理, 43 , 287-297.

石郷岡信行 (1999): 大学進学行動との関わりから みた高等学校進学行動の地域差一岩手県を例と して一。1999 年度人文地理学会大会研究発表要 旨, 108-109.

岩手県教育委員会（1964）：岩手県教育振興基本計 画書. 熊谷印刷, 盛岡。

岩手県教育委員会編（1982）：岩手近代教育史 第 3 巻。熊谷印刷, 盛岡。

岩手県高等学校体育連盟（2000）：平成 11 年度記録 集。トーバン印刷, 盛岡。

浮田典良 (1988)：自宅から高校通学が不可能ない し困難な地域の分布について一全国的概観一。 1988 年度人文地理学会大会研究発表要旨, 9293.

川田力（1992）:わが国における教育水準の地域 格差一大学卒業者を中心として一。人文地理, $44,25-46$.

川田力 (1993)：長野県佐久地方における大学進 学行動と大学新規卒業者の就職行動。地理学評 論, $66 \mathrm{~A}, 26-41$.

川田力 (1997): わが国における専門学校の立地 と進学行動。地域地理研究, 2, 56-70.

川田力 (1998): 高知県の都市システムと高等教 育水準の地域格差一進学行動を中心として一。

森川 洋編: 都市と地域構造。大明堂, 303-324. 木村由紀子（1994）：岩手県における通勤流動に関 する地理学的考察。岩手大学教育学部卒業論文。 後藤雄二（1980）: 岩手県における通勤流動の変化 -1965～1975 年一. 東北地理, 32, 194-202.

酒川 茂（1990）: 英国における初等・中等教育サー ビス供給の地域的差異。広島女子大学文学部紀 要, 25, 27-40.

酒川 茂（1994）：広島市における年少人口減少と 小学校施設の利用状況。広島女子大学文学部紀 要, 29, 17-33.

酒川茂（1997）：英国における成人教育システム の立地と利用一ロンドンのカムデン区とキング ストン区を事例として一。新地理，45-2，1-19.

酒川 茂（1998）：わが国の大都市における公立小 学校の小規模化と自治体の対応。森川 洋編: 都市と地域構造. 大明堂，93-114.

杉浦真一郎 (1997)：広島県における高齢者福祉 サービスと地域的公正. 地理学評論, 70A, 418- 
432.

原田榮（1985）：わが国の教育環境の地域性一予 察的考察一。茨城大学教育学部教育研究所紀要, $18,55-61$.

ピンチ，S. 著，神谷浩夫訳（1990）: 都市問題と公共 サービス。古今書院。Pinch, S. (1985)：Cities and Services: The geography of collective consumption. Routledge and Kegan Paul, London.

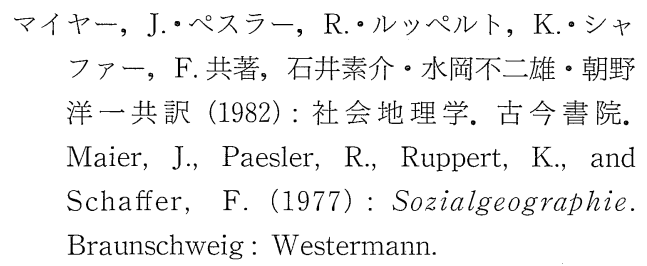

Davies, B.P. (1968) : Social needs and resources in local services. Michael Joseph, London.

\section{Regional Disparities and Time Series Changes in Educational Service Level of High Schools and Behavior of Going on to High Schools in Iwate Prefecture, Japan}

\section{Nobuyuki ISHIGOKA*}

From the standpoint of equal opportunity of education, equal access to educational services must be guaranteed for every person, wherever he or she may live. However, the level of educational services being provided for the people by educational administrations and educational foundations has actually brought about regional disparities quantitatively and qualitatively.

The purpose of this paper is to make clear the regional disparities and time series changes in educational service level of high schools, and the relations between educational service level and behavior of going on to high schools in Iwate Prefecture, northern Japan. Three divisions and fifteen districts are used as areal units for analysis.

The results obtained are summarized as follows;

1) There were regional disparities in the formation of the supplying system of educational services at high schools. That is, establishments of high schools have been promoted since the 1960s in the northeast region of the prefecture, while those movements were almost over in the west and southeast regions before the mid 1960s.

2) The author tried to understand the quantitative regional disparities by the capacity index (the ratio of accommodations for high school freshmen to the number of new leavers from junior high schools). As a result, educational service level has been improved in quantity at every region from 1965 to 1995 . But, the spatial pattern of regional disparities that the capacity index is high in the west region and low in the northeast region has been consistently retained from 1965.

3) As for the provision of vocational (agricultural-forestry-fishery, commercial, technical) education courses at high schools, the quality of educational service level has been improved in majority of districts from 1965 to 1995 . But, there were a few districts where educational service

\footnotetext{
* Iwate Prefectural Ohasama High School, 9-19-1 Ohasama, Ohasama 028-3203, Japan
} 
level has been left in poor situation or cut down. On account of this, regional disparities have become larger comparing with 1965. As for the scale of high schools, it has been reducing throughout the prefecture from 1965. Especially, in the northeast and southeast regions, qualitative decline of educational service level was remarkable, because the percentage of school of which scale was too small to maintain its daily educational activities was increasing. And about the composition of teachers at each district, there was a tendency that the teachers were composed mainly by longer-experienced person in the west region and shorter-experienced in other regions both in 1965 and 1995. Further, the region, where teachers were consisted mainly by longer-experienced, had a tendency that the average length of teacher's services at the same schools was larger. From the above-mentioned results, qualitative regional disparities in educational service level can be pointed out.

4) In 1965, there was positive correlation between the capacity index and the GHS ratio (the number of students who go on to high schools/the number of students who leave junior high schools). But, in 1995, due to the raise of income level and establishment of high schools at peripheral areas and the improvement of traffic convenience, the GHS ratio was over 95 percent in every district regardless of capacity index.

5) In Iwaizumi district that located in the northeastern part of Prefecture, the GHS ratio has been increasing at every settlement from the 1960s to 1980s. But, comparing the 1980s with the 1990s, the GHS ratio was almost same. This means that the GHS ratio had already reached upper limit in the 1980s. As to the relation between GHS ratio and commuting distance of students, the longer the commuting distance was, the lower the GHS ratio was in each period.

Key words : educational service level, regional disparities, behavior of going on to schools, high schools, Iwate Prefecture 